\title{
Demitosisasi Pocong sebagai Media Sosialisasi Kampanye Stay at Home
}

\author{
Wegig Murwonugroho ${ }^{1}$, Alfatri Adlin ${ }^{2}$, Robiana Modjo ${ }^{3}$, dan Moh. Rusnoto Susanto ${ }^{4}$, \\ ${ }^{1}$ Fakultas Seni Rupa dan Desain, Universitas Trisakti, Jl. Kyai Tapa No.1, Grogol Jakarta \\ ${ }^{2}$ Fakultas Seni Rupa dan Desain, Institut Teknologi Bandung, Jl. Ganesha 10, Bandung \\ ${ }^{3}$ Fakultas Kesehatan Masyarakat, Universitas Indonesia, Kampus Baru, Jawa Barat \\ ${ }^{4}$ Fakultas Seni Rupa, Universitas Sarjanawiyata Tamansiswa, \\ Jl. Taman Siswa No. 25, Yogyakarta \\ Tlp. 0818922342, E-mail: wegig@trisakti.ac.id
}

\begin{abstract}
The pocong figure is used by patrol officers at Tuk Songo Village, Purworejo, as an alternative form of socialization media to limit residents' mobility during the pandemic. This research is important in determining the effectiveness of using Javanese mythological ideas as social control for modern society. Pocong is essentially a denotation of sacred objects that are related to the human body that has died and then made into a toy. The research method uses the semiotic method of Roland Barthes. Based on the results of the analysis, there was an excessive response from the community as a connotative meaning. Visible psychological effects in the form of fear and anxiety in the community age group of children and adolescents. Without realizing it, the idea of using the pocong figure is a demythization which was originally a sacred object into a form of media used to deliver messages. This visual play actually reinforces the myth of pocong as the spirits of the dead that can be met in real life by modern people who claim to have faith (remythology). The conclusion of this study is that the demystification of mystical-ritual objects that are told theatrically and humorously continues to build mystical discourses in modern society and succeeds in changing the behavior of residents staying at home. The findings of this study contribute to an effective new approach to disciplining modern society through religious and Java traditions.
\end{abstract}

Keywords: demythology, semiotic, socialization media, myth, pocong.

\begin{abstract}
ABSTRAK
Figur pocong dimanfaatkan petugas ronda Kampung Tuk Songo, Purworejo, sebagai alternatif bentuk media sosialisasi guna membatasi mobilitas warga selama pandemi. Penelitian ini penting untuk dilakukan guna mengetahui efektivitas pemanfaatan gagasan mitologi tradisi Jawa sebagai kontrol sosial terhadap masyarakat moderen. Di mana pocong sejatinya adalah denotasi benda sakral yang memiliki relasi dengan tubuh manusia yang telah mati namun dijadikan mainan. Metode penelitian menggunakan metode semiotik Roland Barthes. Berdasarkan hasil analisis, teridentifikasi adanya respons berlebihan dari masyarakat sebagai bentuk pemaknaan konotatif. Terlihat efek psikologis berupa ketakutan (fear) dan keresahan (anxiety) pada masyarakat kelompok usia anak dan remaja. Tanpa disadari, ide pemanfaatan figur pocong merupakan demitosisasi yang semulanya adalah benda sakral menjadi bentuk media yang dimain-mainkan untuk menghantarkan pesan. Kebermainan visual ini justeru menguatkan mitos pocong sebagai arwah orang mati yang dapat dijumpai dalam kehidupan nyata oleh masyarakat moderen yang mengaku telah beriman (remithology). Simpulan penelitian ini menyatakan bahwa demitosisasi benda mistis-ritual yang dituturkan secara teateritikal kelucuan tetap membangun wacana mistis di tengah masyarakat moderen dan berhasil mengubah perilaku warga tetap di rumah. Temuan penelitian ini menyumbang pendekatan baru yang efektif untuk mendisiplinkan masyarakat moderen melalui tradisi keagamaan dan Jawa.
\end{abstract}

Kata Kunci: demitologi, media sosialisasi, mitos, pocong, semiotik. 


\section{PENDAHULUAN}

Dalam menghadapi pandemi Covid-19 berbagai Iklan Layanan Masyarakat (ILM) berulang kali ditayangkan melalui berbagai media. Ruang-ruang publik, lift, fasilitas transportasi umum hingga toilet tak luput dimanfaatkan sebagai lokasi penempatan media sosialiasi. Lembaga pemerintah dan BUMN terus melakukan feeding di media sosialnya. Meski demikian, sebagian masyarakat di Jawa Tengah tetap ngeyel (Jawa: tidak patuh) melanggar protokol kesehatan, tidak membatasi mobilisasi, dan tetap saja keluar rumah sebagai wujud dari sifat alamiah mahluk sosial. Pemberitaan mengenai rendahnya tingkat kepatuhan masyarakat terhadap protokol kesehatan ini di antaranya banyak diungkap dalam media demakkab. go.id (2021), jatengprov.go.id (2020), dan Firdaus (2020) dalam gatra.com.

Pemberlakuan social dan physical distancing memunculkan efek sosial maupun psikologis, sebagaimana ditemukan dalam penelitian Fitzgerald et al. (2020, hlm. 4-6), berupa munculnya perasaan terkekang dan terintimidasi dalam diri di banyak individu. Dalam situasi lockdown, dengan cara apa pun masyarakat tetap berusaha memperoleh kepastian pendapatan ekonomi, memiliki hak kebebasan sosial keluar rumah, bahkan tak jarang malah mengabaikan keselamatan diri sendiri serta membahayakan orang lain (Kirk \& Rifkin, 2020, hlm. 12).

Pada awalnya respons sosial masyarakat terbagi menjadi dua, yaitu yang mematuhi dan yang mengabaikan dengan berbagai alasan. Namun kini di masyarakat muncul gejala berupa model kepatuhan berlebihan (over-protective) Roy et al. (2020, hlm. 2). Hal ini disebabkan oleh tingginya kekhawatiran masyarakat terhadap Covid-19, yang bahkan mencapai tingkat kekhawatiran 68\% (Yahya, Kompas, 2020).

Akhirnya muncul berbagai respons warga yang berlebihan untuk membatasi mobilitas keluar masuk kampung, serta menahan yang bukan warga setempat untuk memasuki kampung tersebut. Warga menutup seluruh akses masuk menuju kampung mereka, mengklaim daerah mereka sedang lockdown. Jenazah warga daerah setempat yang terkonfirmasi Covid-19 pun ditolak kedatangannya. (Perwitasari, 2020)

Meskipun tampak terproteksi di lingkungan kampungnya sendiri, akan tetapi banyak anak mudanya justru sering terlihat ramai berkumpul di malam hari (Firdaus, Gatra.com, 2020). Fenomena ketidakpatuhan terhadap social dan physical distancing ini kurang terkendali sehingga semakin banyak anak muda bersenda gurau di luar rumah hingga larut malam.

Salah satu bentuk respons atas ketidakpatuhan warga tersebut, maka para petugas ronda jaga malam di Dusun Tuk Songo, Purworejo menggunakan atribut pocong sebagai media untuk menakutnakuti warga agar tetap di rumah. Opsi pocong dipilih sebagai simbol bahaya kematian akibat Covid-19, sekaligus sebagai usaha mengonfrontir golongan masyarakat yang tidak patuh terhadap himbauan stay at home.

Figur pocong dipakai sebagai representasi dalam kampanye sosial melalui visualisasi tanda berupa raut wajah hitam, noda merah darah, dan noda coklat tanah 
di banyak bagian, agar diidentikkan dengan sosok yang bangkit dari dalam tanah sehingga menimbulkan kesan menakutkan. Kesan tersebut semakin diperkuat dengan atribut kain putih sebagai properti untuk mempersonifikasikannya dengan sosok mitologis pocong. Harapannya representasi ini bisa memancing masyarakat untuk berpikir ulang tentang bahaya Covid-19.

Menurut klasifikasi Geertz (1960, hlm. 17-18), pocong termasuk kelompok memedi (hantu) yang kehadirannya tidak mengakibatkan cedera serius. Tatkala dipakai sebagai simbol atau tanda non-linguistik, figur pocong berupaya merekonstruksi pemahaman warga setempat agar mempertimbangkan kembali keputusan mereka untuk keluar rumah. Akan tetapi, keputusan tersebut juga bergantung kepada pemahaman seseorang atas struktur tanda figur pocong sebagai sebuah teks. Dalam hal ini, masyarakat Jawa memahami pocong sebagai sosok mitologis yang leluasa keluar rumah saat malam hari. Secara denotatif, figur pocong memiliki muatan mitos yang bisa direpresentasikan secara visual kepada masyarakat Jawa. Figur pocong juga merepresentasikan sebentuk kekuatan supranatural yang masih diyakini masyarakat Jawa, menakutkan namun tidak sampai membunuh. Makna konotatif ini dipakai agar warga mempertimbangkan kembali keputusan mereka untuk keluar rumah saat malam (Irawan (2012, hlm. 42). Ingatan dan keyakinan inividu biasanya meliputi: mitos, perilaku (ritual), dan objek atau artefak fisik (Gagliardi, 2015, hlm. 179).

Dalam konteks ini, masyarakat dihadapkan kepada kesadaran kolektif yang memersepsikan pocong-pocongan sebagai ancaman psikis berupa rasa takut. Namun karena figur pocong tersebut tidak asli, rasa takut malah tidak muncul sama sekali, bahkan figur pocong itu dijadikan bahan lelucon dan dilempari. Meskipun demikian, dari hasil pengamatan, strategi pemanfaatan figur pocong ini bisa menahan mobilisasi masyarakat keluar rumah. Tetap masih ada sebagian masyarakat yang merasa ragu apakah pocong tersebut palsu ataukah sungguhan. Strategi ini merupakan bentuk siasat budaya yang merepresentasikan kearifan lokal (Rozaki, 2020). Maksudnya, petugas ronda (sebagai kreator) menggunakan mitos pocong untuk melakukan kontrol sosial sebab di dalamnya terkandung nilai yang dianggap benar serta harus diikuti masyarakat.

Namun di sisi lain, malah terlihat kontradiksi dalam masyarakat, yaitu bagaimana individu yang mendapatkan pendidikan agama tetap saja merasa takut kepada sosok pocong yang secara komunal (di masyarakat Jawa) dipandang derajatnya lebih rendah dari manusia. Sebagian masyarakat cenderung memilih menghindari berpapasan dengan pocong daripada terpapar Covid-19. Padahal secara logika medis, pocong sama sekali tidak berbahaya sebagaimana halnya Covid-19.

Penelitian ini berupaya mengungkap secara kualitatif corak khas dalam pemaknaan media. Penelitian ini juga memandang adanya hubungan resiprokal sekaligus kontradiktif antara keyakinan keagamaan dengan kepercayaan mitologis. Dikatakan mempunyai hubungan resiprokal karena tidak ada kejelasan apakah keyakinan 
agama (variabel independen atau kausatif) memengaruhi pemahaman terhadap mitos (variabel dependen atau efek), atau juga sebaliknya. Dikatakan kontradiktif karena ditemukan adanya inkonsistensi dalam keyakinan beragama. Ini terlihat dalam reaksi takut atas sosok yang dalam keyakinan beragama mempunyai derajat lebih rendah.

Oleh karenanya, penelitian ini mengacu pada pertanyaan: (a) bagaimana korelasi mitos pocong dengan keimanan dan logika yang diyakini masyarakat?; dan (b). bagaimana impak psikologis terhadap pemaknaan demitosisasi pocong sebagai media sosialisasi stay at home? Jawaban atas pertanyaan tersebut mengungkap peta kognitif masyarakat subjek.

Olehsebabitu, penelitianiniberkontribusi terhadap khazanah ilmu komunikasi dan estetika dalam beriklan. Temuan ini menjadi dasar empiris pada saat terjadinya pandemi untuk merumuskan kebijakan publik berupa lock down atau kebijakan lainnya yang lebih akomodatif bagi masyarakat.

\section{Konsep Kematian}

Bagi masyarakat Jawa, tubuh manusia terdiri dari tubuh fisik (badan jasmani), tubuh spiritual (badan rohani), dan jiwa (roh suci dan roh nurani) (Woodward, 1985, hlm. 1008-1009). Ketika kematian terjadi, badan rohani dan roh suci terpisah dari badan jasmani. Masyarakat meyakini fase kematian ini adalah awal kehidupan yang kekal (Tanjung, 2017, hlm. 1). Oleh karenanya, langkah pertama dalam pemakaman (layatan) ialah "pembekalan" badan rohani agar bisa menjalani kehidupan baru secara baik (Karim, 2015, hlm. 38).
Ritus pembekalan ini berlangsung sejak seseorang dinyatakan meninggal sampai kemudian dimakamkan. Rangkaian prosesi ini, menurut Aufa (2017, hlm. 2), sebagai bantuan agar jiwa orang mati bisa mencapai akhirat ketika tiba hari kiamat. Demikianlah, masyarakat meyakini badan rohani masih hidup sekalipun badan jasmani telah dipocongkan atau dimakamkan.

Mereka meyakini bahwa badan rohani berada di suatu tempat, dan belum kembali kepada Tuhan, sekurang-kurangnya 3 (tiga) tahun setelah kematiannya. Oleh karenya, sanak kerabat pun melaksanakan slametan atau pengajian agar badan rohani maupun keluarga yang masih hidup sama-sama selamat (Nasir, 2019, hlm. 342).

\section{Pocong dalam Tradisi dan Mitologi Jawa}

Di beberapa daerah tertentu diyakini bahwa roh dari seseorang yang telah meninggal itu mendiami suatu tempat magis dan berinteraksi dengan manusia hidup. (Geertz, 1957, hlm. 43-44). Roh-roh inilah yang oleh Geertz (1960, hlm. 23-24) dikategorikan sebagai dayang dan demit. Walau begitu, dari penelitian Geertz (1960, hlm. 14-29) tentang keyakinan terhadap makhluk halus, hal tersebut sukar digeneralisasikan kepada masyarakat Jawa Tengah, sebab mereka mempunyai pemahaman yang khas.

Bagi mereka, roh gentayangan bisa melakukan beberapa hal dikarenakan kematiannya yang tidak wajar (kecelakaan tragis, dibunuh, atau bunuh diri), pemakaman yang tidak layak, dan pelanggaran berat atas norma sosial selama mereka hidup. Badan rohaninya bisa menampakkan diri, menimbul- 
kan bebunyian (tertawa atau menangis), memindahkan benda, dan berbagai hal sederhana lainnya. Di masa sekarang, mitos semacam itu tidak lantas luntur. Hal ini di antaranya dikarenakan media televisi secara terus menerus menarasikan kisah-kisah mistis sebagai tontonan opera sabun yang disajikan kepada masyarakat (Wessing (2007, hlm. 535).

Hasil pengamatan mengindikasikan bahwa sebagian masyarakat masih mempercayai pocong sebagai badan rohani seseorang. Pocong "tercipta" karena beberapa sebab yang tidak wajar, lalu menuntut balas, sehingga tetap menakutkan. Pocong dinarasikan sering mengganggu orang hidup sehubungan dengan ketidakwajaran kematian maupun pemakaman sebagaimana telah disebutkan.

\section{Trauma Sebagai Efek Psikologis}

Keresahan dan ketakutan merupakan respons emosi alamiah yang terhubung langsung dengan paparan ancaman (Rubin et al., 2016, hlm.303). Bedanya, keresahan (anxiety) adalah respons atas bahaya yang belum terjadi, sedangkan ketakutan (fear) adalah respons atas bahaya yang sedang terjadi. Respons terhadap keresahan atau kekhawatiran mendorong pemikiran untuk memprediksi bahaya yang belum terjadi sekaligus alternatif tindakan untuk menghindarinya. Proses semacam itu tidak terjadi dalam suasana ketakutan, karena bahaya dan respons dalam ketakutan tidak diperkirakan sebelumnya.

Adapun respons terhadap ketakutan berisiko lebih besar dalam menyisakan trauma. Namun, dikarenakan pengalaman merespons ketakutan - tanpa persiapan psikologis - trauma yang timbul justru berkontribusi terhadap keresahan-keresahan berikutnya. Praktis, individu mengalami PostTraumatic Stress Disorder (PTSD), yang muncul karena jalinan ketakutan dan keresahan. Hal itu ditandai dengan respons ketakutan secara terus menerus terhadap isyarat yang berhubungan dengan pengalaman atau peristiwa penyebab trauma (Zoellner et al., 2020, hlm. 47-48).

Relevansi konsep di atas dengan riset ini adalah: pengalaman penyebab ketakutan dan kecemasan tidak terbatas pada pengalaman aktual saja, akan tetapi termasuk pengalaman spiritual.

Sebagaimana penjabaran dalam penelitian Kay et al. (2010, hlm. 37), keyakinan agama menjadi satu-satunya kontrol kompensatoris ketika kontrol personal dan eksternal sedang lemah. Itu merupakan sumber dari kontrol pribadi dan eksternal untuk menghilangkan kecemasan atas suatu pengalaman. Kepercayaan atas Tuhan serta ajarannya menjadi pilihan terakhir ketika kemampuan intelektual dan sosial individu tidak mampu menerima pengalaman buruk.

Walau definisi baku dari pengalaman traumatis penyebab PTSD adalah peristiwa yang mengancam kehidupan, tetapi bukti yang ada menunjukkan bahwa tipe-tipe ancaman lain juga berperan dalam pembentukan PTSD. Itulah mengapa penelitian ini memandang mitos pocong sebagai stressor pemicu PTSD pada individu yang memercayai pocong sebagai badan rohani dari orang mati.

Meskipun korelasi antara mitos dengan keyakinan beragama dalam kehidupan seharihari sering diabaikan, namun hal itu akan kembali berfungsi secara spontan (recall) ketika 
muncul peristiwa yang menggambarkan mitos tersebut. Pada akhirnya mitos selalu menjadi perwujudan filosofis dari suatu nilai dalam arti sakral (Ihejirika \& Edodi, 2017, hlm. 203). Dalam konteks penelitian ini, pengetahuan mitos menduduki suatu wilayah imajiner yang mendasari sikap atau tindakan seseorang.

\section{METODE}

Penelitian kualitatif ini menganalisis visualisasi pocong menggunakan semiologi Roland Barthes (1967, hlm. 95). Semiologi Barthes dianggap paling sesuai karena mendudukkan mitos dalam sistem semiotika. Barthes mendefinisikan mitos sebagai persepsi yang dibangun di atas ideologi masyarakat kontemporer. Mitos berperan sebagai sarana untuk mendistorsi fakta, sehingga masyarakat menerimanya tanpa ada penjelasan narasi panjang untuk meyakinkan apa pun yang dimitoskan.

Analisis semiotika Barthes punya kesamaan preferensi dengan pemahaman masyarakat. Sebagaimana dinyatakan Barthes (1972, hlm. 107-108), penerapan mitologi hanya dapat memiliki dasar yang bersifat historis, yang dalam kasus visualisasi sejarah pocong di penelitian ini telah berkembang sejak lama. Secara runtut, penelitian ini dilaksanakan mengkuti prosedur berikut.

Penelitian ini menguraikan makna denotatif, konotatif, dan mitos dengan mempelajari tanda yang melekat pada pocong palsu, kemudian menghubungkan pemaknaan dan respons atas tanda tersebut. Penelitian ini berfokus pada analisis atas makna konotasi. Sebagai level kedua dari sistem semiotik,
Skema 1. Tahapan Metode Peneltian

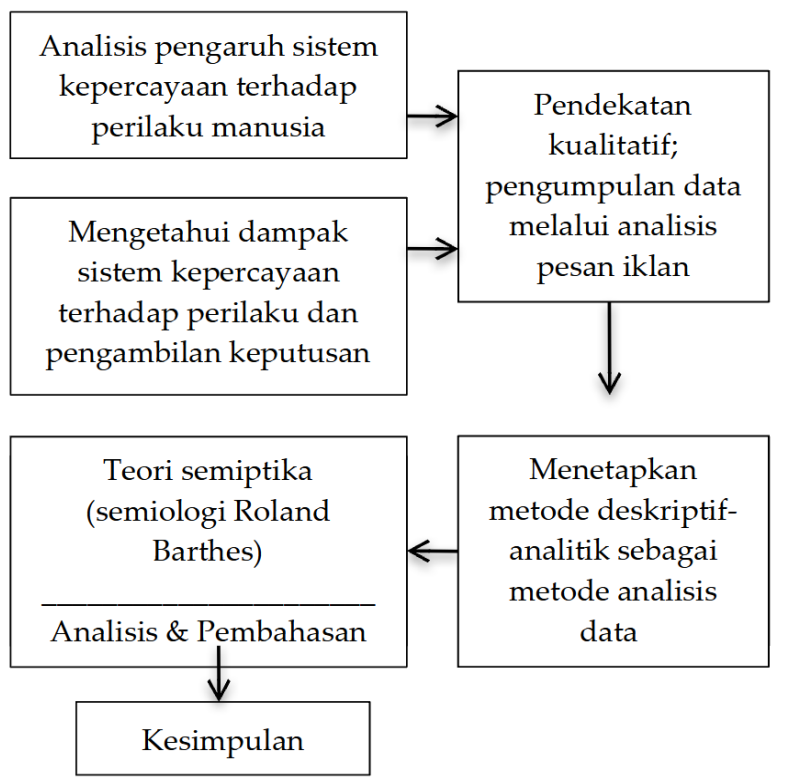

makna konotasi mampu mengungkap dan menjelaskan subjektivitas manakala dikaitkan dengan emosi dan keyakinan. Guna mendapatkan makna konotasi secara utuh, penelitian ini menggunakan unsur budaya dan ideologi religi masyarakat (Monticelli, 2016, hlm. 442).

\section{HASIL DAN PEMBAHASAN}

\section{Analisis semiotik dalam figur pocong}

Menurut semiologi Roland Barthes, objek iklan terdiri dari tanda denotasi dan konotasi yang merepresentasikan makna atau mitos yang ingin disampaikan pembuatnya. Figurasi pocong palsu menunjukkan struktur tanda denotatif. Penyamar berusaha merepresentasikan entitas imajiner mereka sebagaimana diyakini menurut referensi kebudayaan dan keagamaan. (Gambar 1)

Berdasarkan visualisasi di Gambar 1, pocong tidak menampakkan tanda verbal, dan sepenuhnya menampilkan tanda visual. Tanda visual tersebut meliputi warna, bentuk, dan 


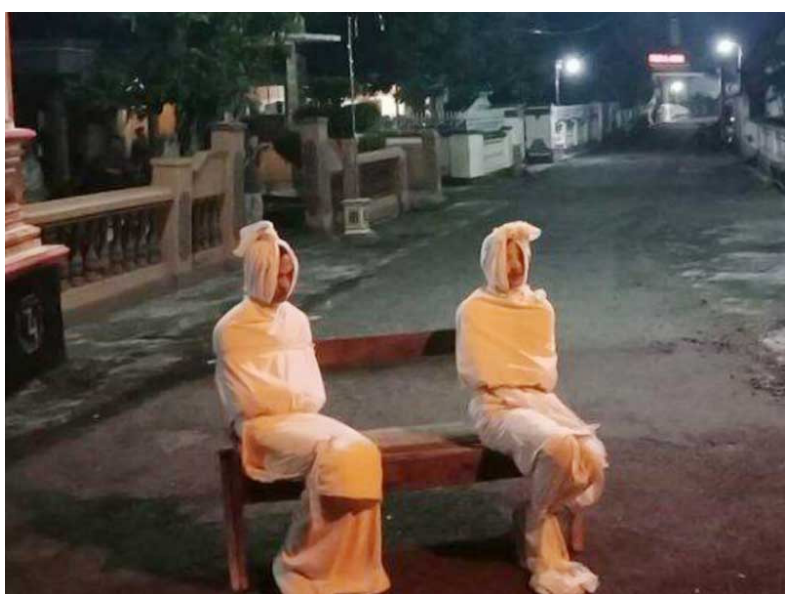

Gambar 1. Visualisasi sosok pocong (Sumber: https://www.wowkeren.com /berita/ tampil/00304027.html, 2020)

posisi. Ditinjau dari warna, figurasi pocong didominasi warna putih, disertai warna kusam (noda darah dan tanah). Penampakan yang demikian mampu memberi kesan seram karena menandakan sosok tersebut telah mati, telah dikubur, tubuhnya telah membusuk, namun kemudian bangkit. Tanda visual warna itu merupakan signified dan signifier yang paling mudah dilihat serta dibaca orang lain (Chandler, 2007, hlm. 38; Murwonugroho \& Miftakhuddin, 2020, hlm. 291). Terlebih lagi dengan munculnya warna putih yang dominan di malam hari yang dominan gelap (identik dengan warna hitam). Sebagaimana diketahui, warna hitam itu asosiatif dengan suram, menakutkan, dan misterius.

Pencahayaan yang redup--sehingga identik dengan kegelapan atau malam-merupakan indeks, sebab mempunyai kaitan fisik, eksistensial, atau kausal antara representament dan objeknya (Budiman, 2003, p. 91). Dengan demikian, perbedaan warna yang kontras menjadikan warna putih tampak mencolok di tengah-tengah warna hitam (gelap). Berdasarkan asumsi itu, seseorang sudah bisa me-recall referensinya tentang orang mati, roh badani dari orang mati, jasad atau badan yang membusuk, dan berbagai konsep lainnya tentang kematian yang diperkenalkan budaya hanya dengan menggunakan tanda visual warna.

Interpretasi tanda visual warna putih yang dominan pada media pocong menjadi semakin kuat karena didukung tanda visual berupa bentuk dan posisi. Tanda visual bentuk menggambarkan bungkusan kain putih yang membentuk postur tubuh manusia dengan kaki terikat dan tangan terlipat di depan pusar, serta tanda visual berupa sisa kain putih yang dikuncir di bagian atas. Meski ada tanda visual berupa wajah, namun visualisasi tersebut sekilas tidak menunjukan bahwa sosok tersebut mengikuti postur tubuh manusia, karena seolah tanpa tangan serta kedua kaki (lebih menyerupai tiang atau tugu). Terlihat bahwa sang kreator memiliki pengalaman religius-kebudayaan dalam upacara pemakaman adat Jawa.

Secara denotatif figur pocong itu berupa objek yang hampir menyerupai bentuk manusia dalam bungkus kain putih kusam dengan bercak noda tanah dan darah. Kemudian ada tali kuncir di ujung kepala dan ujung kaki, sedang tangan dilipat di depan dada dan terdapat kapas di lubang hidung.

Adapun pemaknaannya secara konotatif, hal itu menyiratkan keresahan, ketidaktenangan, dan kengerian. Pemaknaan tersebut merujuk pada pemahaman kultural masyarakat Jawa dengan membangkitkan kembali mitos bahwa pocong adalah representasi dari jiwa manusia yang banyak melanggar norma dan aturan-aturan. Dalam konteks kontrol sosial selama masa pandemi 
Covid-19 yang mengharuskan masyarakat untuk stay at home, analisis Barthes memandang mitos sebagai instrumen untuk mengendalikan perilaku publik.

Meskipun demikian, baik tanda visual bentuk maupun tanda visual warna berkontribusi secara signifikan terhadap keberhasilan pembacaan seseorang atas figur pocong; sedangkan tanda visual posisi duduk kurang berkontribusi. Dalam kasus penelitian ini, posisi pocong palsu berada di tengah keramaian manusia. Padahal menurut mitologi masyarakat Jawa, pocong selalu berada di tempat sepi yang jarang dilewati manusia. Demikian pula halnya dengan posisi duduk yang ditampakkan justru sangat kontradiktif dengan mitologi pocong yang selalu dalam posisi berdiri. Karenanya, revitalisasi mitos yang dilakukan tersebut malah menjadi demitologi. Dalam hal ini, demitosisasi mengkonstruksi mitos pada satu pemaknaan tertentu, sekaligus mengulangi mitos atau remythology pada pemaknaan lainnya (Womack \& Davis, 2006, hlm. 99). Demitosisasi juga mengabaikan yang sakral.

\section{Fase Perubahan Respons dan Kognisi}

Sebagaimana telah ditegaskan dalam landasan teori, penelitian ini mengungkap adanya dua bentuk respons, yaitu keresahan (anxiety) dan ketakutan (fear). Semua subjek menunjukkan gejala ketakutan lebih dulu. Bagi anak dan remaja, penggunaan pocong memunculkan mitos berupa kengerian dari alam kematian. Ini sesuai dengan tujuan penggunaan figur pocong berdasarkan analisis semiologi di atas, bahwa penggunaan pocong membawa kepentingan demitologi dan remitologi. Gunanya adalah untuk menguatkan pesan dalam kampanye sosial stay at home. Oleh karena itu, peneliti menyimpulkan bahwa demitosisasi pocong berkontribusi terhadap keberhasilan pemerintah dalam mengondisikan masyarakat agar stay at home.

Kampanye sosial menggunakan figur pocong memunculkan ciri yang turut mengkonfirmasi strategi promosi dalam pandangan Lee \& Johnson (2005, hlm. 22), bahwa iklan di luar ruangan merupakan cara terbaik untuk menjangkau orang-orang yang sering berada di luar rumah, terlebih lagi media dari kampanye sosial ini pun tidak lazim. Kontribusi ini dapat diamati dalam fase perubahan respon dan kognisi masyarakat.

Padafase pertama, pocong memunculkan rasa takut. Bagi anak-anak di bawah 11 tahun, rasa takut tersebut berlanjut ke fase kedua, yaitu menjadi kekhawatiran atau keresahan (Tabel 1). Hal ini sesuai dengan penjabaran teoretik di muka, bahwa ketakutan yang berlanjut menjadi kekhawatiran merupakan gejala awal dari trauma berat. Akan tetapi yang menarik adalah fakta bahwa pengalaman yang membekas di benak anak-anak pada gilirannya akan mengubah struktur kognisi mereka (Piaget, 1965, hlm. 110). Alasannya karena pengetahuan anak tentang pocong yang selama ini hanya berupa sosok figuratif (tidak begitu menyeramkan), kini menjadi sosok konkret menyeramkan yang memberi sensasi kaget.

Inilah yang oleh Piaget (2003, hlm. 6) disebut sebagai rekonstruksi kognisi, yaitu perubahan struktur kognisi yang disebabkan oleh ketidaksamaan antara konsep abstrak 
Tabel 1. Efek traumatis pocong palsu terhadap psikis individu

\begin{tabular}{cll}
$\begin{array}{c}\text { Jenjang } \\
\text { usia }\end{array}$ & \multicolumn{1}{c}{ Efek traumatis } & \multicolumn{1}{c}{ Kecenderungan akhir } \\
\hline Anak-anak & $\begin{array}{l}\text { Ketakutan, } \\
\text { berlanjut menjadi } \\
\text { kekhawatiran } \\
\text { hingga trauma }\end{array}$ & $\begin{array}{l}\text { Anak-anak cenderung mengalami trauma lebih parah } \\
\text { daripada remaja dan orang dewasa. }\end{array}$ \\
& Ketakutan, \\
berlanjut menjadi & $\begin{array}{l}\text { Tingkat keparahan trauma bergantung pada } \\
\text { kekhawatiran }\end{array}$ & $\begin{array}{l}\text { menangkap pesan yang dimitoskan dalam figur } \\
\text { pocong, maka efek traumatis yang ditimbulkan } \\
\text { cenderung berkelanjutan. Pun demikian sebaliknya. }\end{array}$ \\
\hline \multirow{2}{*}{$\begin{array}{l}\text { kewasa } \\
\text { Ketakutan }\end{array}$} & $\begin{array}{l}\text { Orang dewasa cenderung mengalami trauma ringan, } \\
\text { bahkan tidak sama sekali. }\end{array}$ \\
\hline
\end{tabular}

yang diyakini dengan situasi nyata yang dialami. Pada tahap perkembangan kognitif ini, pengetahuan yang sudah mapan (equilibrium) mendapat stimulus berupa pengetahun baru yang kontradiktif terhadap pengetahuan yang sudah mapan. Dengan demikian, maka terjadilah disequilibrium. Dalam hal ini, figur pocong yang ditemui anak berperan sebagai stimulus yang memicu terjadinya disequilibrium. Ketika tidak ada lagi pemicu disequilibrium, maka pengetahuan baru terbentuk dalam struktur kognisi individu sebagai equilibrium baru (Ormrod, 2016, hlm. 281).

Berbeda dengan kecenderungan pada anak, fase perubahan di kalangan remaja sangat bergantung kepada kemampuan mereka menginterpretasikan figur pocong. Jika mereka bisa memahami mitos yang dipromosikan penyamar, yaitu bahwa melanggar protokol kesehatan merupakan aktivitas mendekati kematian, maka respons defensif yang timbul adalah ketakutan. Jika tidak, malah akan berlanjut menjadi kekhawatiran seperti terjadi pada anak-anak.

Dampak lebih lanjutnya adalah muncul keresahan traumatik terhadap benda-benda yang identik dengan pocong, baik yang mengandung tanda visual warna, tanda visual bentuk, maupun tanda visual posisi (lihat Gambar 1).

Meski demikian, remaja yang gagal menginterpretasikan mitos tersebut tetap memperoleh pembelajaran sebagai proses psikologis (El-Shamy, 1967, hlm. 13; Miftakhuddin et al., 2019, hlm. 21). Peristiwa ini direkam dalam memori sebagai bentuk untuk menginterpretasikan figur lain dalam mitos lain. Sedangkan bagi orang dewasa, kecenderungan yang muncul adalah kecilnya efek traumatis. Dalam beberapa kasus, bahkan tidak menimbulkan efek traumatis. Oleh sebab itu, kognisi mereka lebih mudah menerima figurasi pocong sebagai alternatif untuk 


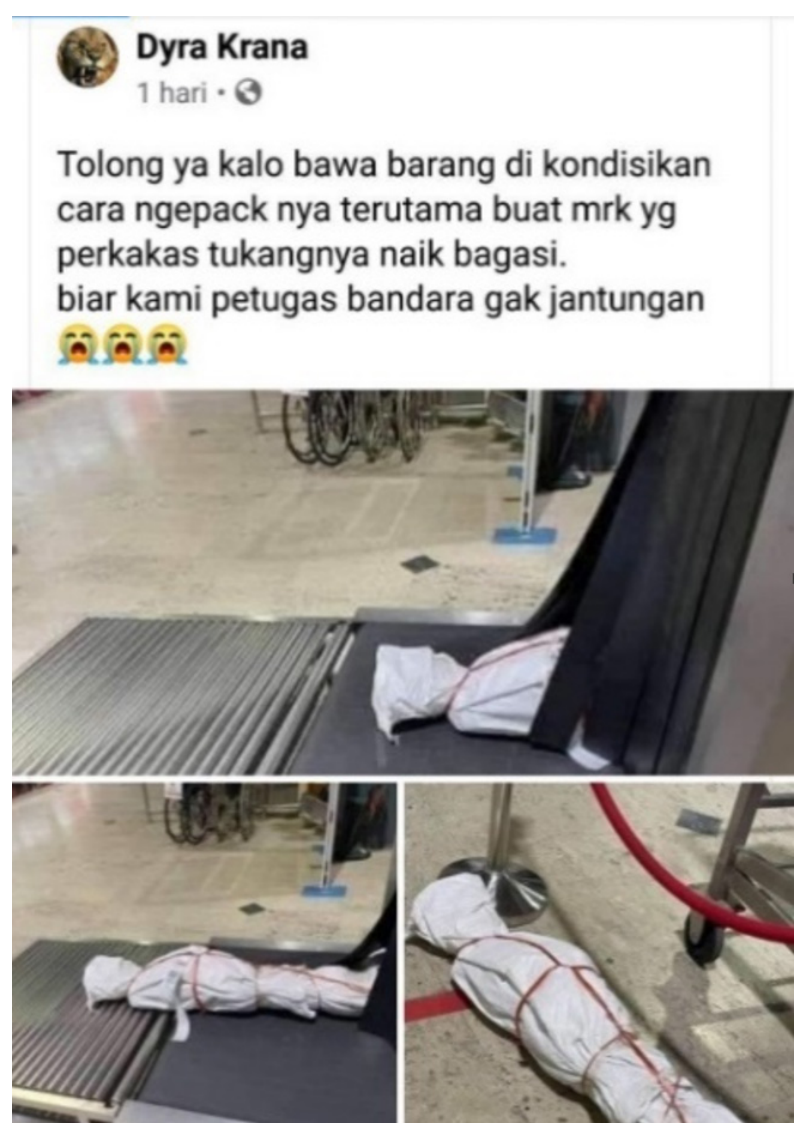

Gambar 2. Denotasi bentuk pocong yang memunculkan konotasi menyeramkan. (sumber: dokumen pribadi, 2021)

mengendalikan perilaku seseorang manakala metode yuridis yang dikampanyekan pemerintah malah tidak efektif.

Simbol-simbol kematian memang lazim dipergunakan selama pandemi. Bahkan di Jakarta, peti mati diusung di jalanan ramai untukmengampanyekan betapaberbahayanya Covid-19 (Tempo, edisi 12-13 September 2020). Dengan demikian, pemakaian mitos untuk kematian akibat Covid-19 telah muncul di berbagai tempat, dan dilakukan secara berulang. Hasil yang kemudian diperoleh adalah perubahan perilaku masyarakat. Akan tetapi temuan penelitian ini justru menunjukkan tren yang sedikit berbeda, begitu pula dengan temuan Scarnera (2016). Berdasarkan risetnya, Scarnera (2016, hlm. 3) menyimpulkan bahwa masyarakat akan mengubah perilakunya jika tanda-tanda denotasi dan konotasi ditampakkan secara terus-menerus. Sedangkan dalam penelitian ini, kontinuitas tanda denotatif dan konotatif tidak begitu berpengaruh.

Menurut analisis lebih lanjut, tren ini terbentuk atas peran media sosial. Sebagai produk cyber cultures, media sosial memberi informasi dan merekonstruksi persepsi publik tentang kecemasan sekaligus menciptakan pilihan perubahan sosial. Peran ini mendorong perubahan media sosial di ruang virtual menjadi sarana edukasi publik yang praktis sekaligus sarana perubahan sosial yang kontekstual (Susanto et al., 2019, hlm. 522). Media sosial menjadi ranah yang penting untuk merespons suatu visualisasi seni tanpa melihat fisiknya. Terlepas dari memancing munculnya suatu wacana atau tidak, seni berpeluang mendominasi ranah media sosial sebagai ruang publik digital. Studi ini mengonfirmasi temuan Susanto et al. (2019, hlm. 462), bahwa fakta sosial yang melingkupi isu substansial memicu perubahan kultural dan mengubah karakteristik masyarakat kontemporer yang kini juga mempunyai kehidupan dalam dunia digital.

\section{Subjektivitas terhadap Mitos dan Agama}

Penelitian ini menemukan adanya inkonsistensi masyarakat dalam melihat sosok mitologis sebagai entitas fiktif. Sebagai komunitas beragama, seharusnya prinsip keimanan masyarakat itu tercermin dalam perilaku praktis sehari-hari (Ihejirika \& Edodi, 2017, hlm. 196). Termasuk dalam hal ini juga adalah kepercayaan yang menganggap pocong sebagai ciptaan Tuhan dengan derajat 


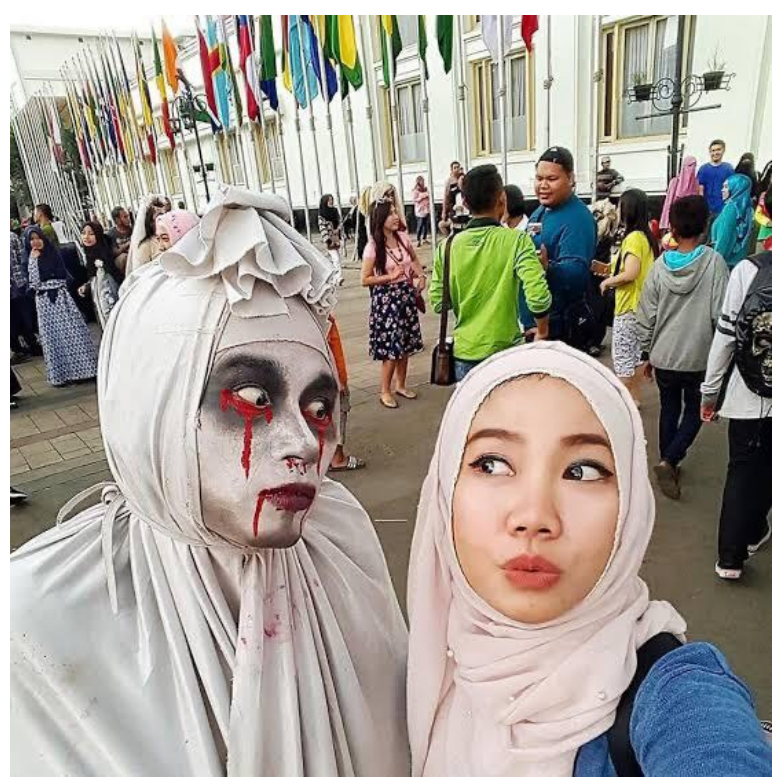

Gambar 3. Demitosisasi pocong wisata narsis di depan gedung KTT Asia Africa, Bandung

(sumber: travelingyuk.com, 2021)

yang lebih rendah dari manusia. Oleh karena itu, idealnya masyarakat yang bertemu pocong palsu tidak menunjukkan respons ekstrem.

Namun begitu, respons defensif yang ditemukan dalam penelitian ini mengindikasikan sebaliknya. Mereka bisa mengabaikan protokol kesehatan Covid-19 yang berisiko kematian, sebab kematian telah ditentukan oleh Tuhan. Akan tetapi, di sisi lain, mereka takut dan/atau khawatir atas pocong, sebagai sosok mitologis yang dipercaya juga sebagai ciptaan Tuhan. Artinya, masyarakat punya kepercayaan dan kewaspadaan lebih besar terhadap segala hal yang berdampak langsung dan praktis, daripada sesuatu yang mempunyai nilai-nilai ideologis.

Secara psikologis, ini terjadi karena figur pocong sebagai aset mitos yang ditampilkan melalui media itu terbawa ke alam bawah sadar, sehingga masyarakat cenderung lebih memercayai mitos. Namun, psikis manusia akan kembali normal manakala figur pocong dipertontonkan berulangkali sebagai lelucon
(Gambar 3). Bila mana manusia sudah terbiasa dengan situasi tersebut, maka secara tidak disadari telah terjadi proses demitosisasi. Kesakralan, ideologi yang pada awalnya dianggap sebagai sesuatu penting kini berangsur menjadi permainan.

Sartono Kartodirdjo pernah menyebut lima dimensi religiusitas, yaitu: 1). pengalaman; 2). ideologis; 3). spiritual; 4). intelektual-ideal; dan 5). konsekuensial. Subjektivitas masyarakat dalam beragama, terkait dengan lima dimensi di atas, didominasi oleh pengalaman, intelektual-ideal, dan konsekuensial. Masyarakat mengabaikan dimensi ideologis dan spiritual karena tidak memberikan dampak langsung dan praktis bagi kehidupan beragama. Artinya, pada taraf ini masyarakat menganggap pemikiran mitos tradisional sebagai sesuatu yang kurang penting dibandingkan pemikiran logis (Morales, 2013, hlm. 34). Elaborasi penelitian ini mendapati bahwa mitos lama bisa memudar karena adanya mitos baru yang menjamah sisi kebudayaan kontemporer, modern, kekinian, dan pengetahuan kolektif masyarakat."

\section{Kecenderungan Pemaknaan Mitos Pocong}

Dampak perubahan sosial yang didorong oleh kebijakan politik-kesehatan juga berpengaruh terhadap pemilihan media beriklan. Gagasan menghadirkan pocong bukan sekadar shock therapy, melainkan juga sebentuk katarsis bagi kesadaran masyarakat manakala diharuskan menaati protokol kesehatan. Hal ini tergambar jelas dalam pernyataan Starner (2020, hlm. 242); bahwa kebutuhan akan kontak dan saling terkoneksi 
yang semakin meningkat akan berubah menjadi kecemasan tersendiri.

Dalam penelitian ini terungkap sejumlah efek traumatis lelucon pocong palsu terhadap psikis individu. Berdasarkan analisis semiotik Barthes, lelucon pocong menghasilkan interpretasi makna yang tidak sama pada masing-masing kelompok usia. Pocong palsu berkorelasi langsung dengan referensi imajiner dalam pikiran subjek yang telah direkonstruksi melalui kebudayaan dan secara keagamaan. Manakala subjek melihat sosok pocong palsu, ingatannya mengacu kepada bentuk manifest yang selama ini diyakini sebagai perwujudan badan rohani dari orang mati.

Anak-anak, remaja, maupun dewasa, memaknai bentuk lelucon pocong dengan cara yang sama. Pemaknaan yang didasarkan atas referensi imajiner hasil rekonstruksi kultural dan religius meneguhkan bahwa pocong tersebut memiliki penampakan yang tidak terlalu menyimpang. Akan tetapi dikarenakan adanya mitos yang berkembang tentang badan rohani dari orang mati, maka permainan media visual lelucon pocong tetap saja menyeramkan. Sebagaimana penelitian Murwonugroho \& Tyasrinestu (2019, hlm. 3697), komodifikasi tanda menciptakan perbedaan atau oposisi biner. Komodifikasi ini tidak hanya imajinatif, sureal, fantasi, namun juga memerlukan permainan visual (visual play). Pocong, sebagai media, juga memanfaatkan lingkungan fisik (suasana malam) untuk penempatannya; inilah salah satu bentuk dari ambient media.

Terlepas dari efektivitas lelucon pocong sebagai instrumen media kontrol sosial, mitos pocong pun masih menempati ruang khusus dalam peta kognitif masyarakat. Namun begitu, telah terjadi pergeseran makna dari sesuatu yang semula dianggap sakral atau kudus menjadi bahan lelucon. Pada generasi lampau, pocong dianggap sebagai badan rohani dari orang mati; sedangkan bagi generasi kini, figur pocong dianggap sebagai sesuatu yang bisa dijadikan lelucon atau mainan, meskipun dalam kognisi dan memori mereka masih tersimpan referensi bahwa pocong identik itu dengan orang mati.

Berdasarkan kecenderungan tersebut, penelitian ini menyimpulkan bahwa mitos tentang pocong dimanfaatkan sebagai instrumen komunikasi iklan. Mitos tersebut menjadi media pembawa pesan dari pengguna (kreator) kepada penonton (masyarakat) agar tetap berada di dalam rumah. Lebih dari itu, menurut analisis makna konotatif terhadap figur pocong, secara tidak sadar kreator telah melakukan demitosisasi dengan mempromosikan mitos baru, yaitu "siapa pun yang melanggar peraturan akan menemui kesulitan, terutama pasca kematian." Namun yang menarik bahwa penyebab pergeseran ini sama dengan penyebab pergeseran makna yang terjadi dalam riset Gora et al. (2020), yaitu bagaimana kehilangan identitas terjadi justru dikarenakan kurangnya literasi budaya dan sejarah.

\section{SIMPULAN}

Penelitian ini menyimpulkan bahwa demitosisasi terjadi karena adanya dekonstruksi penandaan benda ritual. Asumsi tersebut ditandai oleh hilangnya kesakralan 
pocong ketika kampanye sosial menggunakan media pocong palsu yang disajikan berulang secara terus menerus. Pada fase awal, keimanan dan nalar tidak berfungsi dengan baik manakala individu sedang merasa kaget, takut, cemas, dan trauma. Respons spontan ini akan berkurang dengan kemunculan gagasan pocong, keranda mayat, dan objek lain sejenis sebagai bentuk kreatif sosialisasi protokol kesehatan melalui media-media sosial. Namun demikian, keresahan bertemu pocong sungguhan menjadi alasan mengapa masyarakat tetap memilih untuk stay at home, meskipun mengaku memiliki iman yang kuat dan telah menjadi bagian dari masyarakat modern. Simpulan pertama dalam artikel ini menyatakan bahwa korelasi antara keimanan dengan logika masyarakat terhadap mitos pocong tidak berfungsi ketika mengalami kecemasan dan trauma.

Penelitian atas persepsi dan pemaknaan tanda dalam demitosisasi media pocong ini merumuskan tiga temuan sebagai berikut. Pertama, strategi kampanye sosial menggunakan mitologi tradisi Jawa (pocong) terbukti efektif menyadarkan masyarakat Jawa "modern" untuk tetap tinggal di rumah, namun menyebabkan trauma bagi masyarakat kelompok umur tertentu. Kedua, sosok pocong palsu memainkan perannya sebagai bentuk ambient media yang memanfaatkan lingkungan fisik berupa kegelapan malam. Audiens mau tidak mau dikondisikan harus berhadapan dengan sebentuk tanda pocong, langsung membaca pesan yang disematkan, memaknainya untuk kemudian merasa kalut dan menjauhi media pocong tersebut karena diingatkan kepada mitos posong tersebut.
Ketiga, seseorang malah menjadi lebih takut kepada sesuatu yang tampak tapi tidak berbahaya (pocong-pocongan) daripada yang tidak tampak tapi bahaya (Virus Covid-19) karena figur yang tampak tersebut telah "direkam" lebih dulu dalam psikis manusia, telah direkonstruksi melalui aktivitas budaya dan keagamaan, telah melekat dalam persepsi, kognisi, dan memori untuk kemudian diproyeksikan kepada benda-benda yang mempunyai kesamaan identitas visual dengan pocong.

Simpulan kedua menyatakan bahwa persepsi dan pemaknaan tanda terhadap demitosisasi pocong itu bersifat situasional. Ketika suasana (ambience) di sekeliling media pocong membangun suasana menyeramkan, maka kehadiran pocong justru semakin menguatkan persepsi bahwa mitos pocong yang bangkit dari kubur adalah benar-benar nyata. Namun berbeda dengan suasana di siang hari dengan keramaian publiknya, figur pocong tersebut dianggap sebagai lelucon dan mainan, yang malah memudarkan mitos pocong sebagai figur menakutkan. Pemanfaatan pocong pada media sosialisasi ini membangun suatu persepsi di sebagian kalangan masyarakat Jawa untuk tetap tinggal di rumah.

Perekaman figur yang tampak banyak dipengaruhi oleh media sosial, yang berperan merekonstruksi persepsi publik terhadap disakralkan atau tidaknya sebuah gagasan. Atas peran media sosial pula, figur pocong sebagai wujud lanjutan tubuh ciptaan Tuhan - yang awalnya ditakuti, disakralkan - kini menjadi bahan mainan. 
Pocong palsu bukanlah sekadar shock therapy, melainkan juga sebentuk katarsis dari kesadaran masyarakat untuk menaati protokol kesehatan. Hal ini dibuktikan dengan terbangunnya wacana yang mengubah perilaku masyarakat agar membatasi mobilitas justru dengan cara dengan menghilangkan keangkeran pocong. Sekalipun dituturkan secara teatritikal lagi lucu, namun demitosisasi pocong sebagai benda mistis-ritual tetap membentuk wacana takhayul di tengah masyarakat Jawa modern, bahkan berhasil mengubah perilaku warga agar tetap berada di dalam rumah.

Berdasarkan simpulan di atas, kontribusi penelitian ini adalah: (1) untuk pengembangan ilmu, penelitian ini menawarkan tanda-tanda aspek budaya sebagai perspektif baru bagi content dalam media kampanye pembatasan sosial yang selama ini belum banyak dijelaskan melalui perspektif sosiologi; (2) bagi pejabat pemerintah desa maupun kota, penelitian ini memberi alternatif baru untuk mendisiplinkan masyarakat secara lebih manusiawi, sebab penelitian ini mengungkapkan bahwa pendekatan humanistik itu lebih berhasil daripada pendekatan behavioristik; bagi akademisi, penelitian ini berkontribusi bagi dasar pedoman untuk beriklan dengan memenuhi unsur etika dan etiket. Secara praktis, kontribusi ketiga itu layak untuk diajukan sebagai pendekatan budaya menggantikan pendekatan hukum yang sering dilanggar selama pemberlakuan lock down di masa pandemi ini.

\section{DAFTAR PUSTAKA}

Aufa, A. A. (2017). Makna kematian dalam perspektif tasawuf. An-Nas: Jurnal Humaniora, 1(1), 1-11. https://doi. org/10.1017/CBO9781107415324.004

Barthes, R. (1967). Elements of semiology. Hill and Wang.

Barthes, R. (1972). Mythologies. Hill and Wang. Budiman, K. (2003). Semiotika visual. Yayasan Seni Cemeti.

Chandler, D. (2007). Semiotics the basics. Routledge.

Demakkab.go.id. (2021). Stay at home, langkah efektif tekan penularan covid-19. Diakses pada 20 September 2021. https:// dinkominfo.demakkab.go.id/berita/ detail/stay-at-home-langkah-efektiftekan-penularan-covid19

El-Shamy, H. M. (1967). Folkloric behavior: A theory for the study of the dynamics of traditional culture. Indiana University.

Firdaus, F. (2020). Polisi Tegal edukasi masyarakat social distancing. Diakses 21 September 2021. https://www.gatra.com/detail/ news/473160/hukum/polisi-tegaledukasi-masyarakat-soal-socialdistancinghttps://www.gatra.com/ detail/news/473160/hukum/polisitegal-edukasi-masyarakat-soal-socialdistancing

Fitzgerald, D. A., Nunn, K., \& Isaacs, D. (2020). Consequences of physical distancing emanating from the COVID-19 pandemic: An australian perspective. Paediatric Respiratory Reviews. https:// doi.org/10.1016/j.prrv.2020.06.005

Gagliardi, P. (2015). Myths and symbols: Organizational. International Encyclopedia of the Social \& Behavioral Sciences: Second Edition, 16(1990), 179182. https://doi.org/10.1016/B978-0-08097086-8.73088-1

Geertz, C. (1957). Ritual and social change: A Javanese example. American Anthropologist, 59(1), 32-54.

Geertz, C. (1960). The religion of Java. The University of Chicago Press.

Ihejirika, C. I. C., \& Edodi, S. O. (2017). Myths as contextual logic for social control: The Igbo example. African Research Review, 11(4), 192-207. https://doi. 
org/10.4314/afrrev.v11i4.16

Irawan, A. M. (2012). Mythology construction in cosmetic advertisements adnd consumers' cognition. Jurnal Inovasi Dan Kewirausahaan, 1(1), 38-46.

Jatengprov.go.id. (2020). Tak patuhi protokol kesehatan, pelanggar dijatuhi sanksi kerja sosial. Diakses 21 September 2021. https://jatengprov.go.id/beritadaerah/ tak-patuhi-protokol-kesehatanpelanggar-dijatuhi-sanksi-kerja-sosial/

Karim, A. (2015). Makna kematian dalam perspektif tasawuf. Esoterik, 1(1), 21-46.

Kay, A. C., Gaucher, D., McGregor, I., \&Nash, K. (2010). Religious belief as compensatory control. Personality and Social Psychology Review, 14(1), 37-48. https://doi. org $/ 10.1177 / 1088868309353750$

Kirk, C. P., \& Rifkin, L. S. (2020). I'll trade you diamonds for toilet paper: Consumer reacting, coping and adapting behaviors in the COVID-19 pandemic. Journal of Business Research, 117, 124-131. https:// doi.org/10.1016/j.jbusres.2020.05.028

Lee, M., \& Johnson, C. (2005). Principles of advertising: A global perspective. Routledge. https://doi. org/10.4324/9780203050262

Miftakhuddin, Mustadi, A., \& Zulfiati, H. M. (2019). Misconceptions between social studies and social sciences among pre-service elementary teachers. International Journal of Education, 12(1), 16-25. https://doi.org/10.17509/ije. v12i1.17514

Monticelli, D. (2016). Critique of ideology or/and analysis of culture? Barthes and Lotman on secondary semiotic systems. Sign Systems Studies, 44(3), 432-451. https://doi.org/10.12697/ SSS.2016.44.3.07

Morales, S.S. (2013). Myth and the Construction of Meaning in Mediated Culture. Kome: An International Journal of Pure Communication Inquiry, 1(2), 33-43. https://doi.org/10.17646/kome.2013.13

Murwonugroho, W., \& Miftakhudin, M. (2020). Kajian Rupabheda: TokohTokoh Sri Tanjung pada Relief Candi Penataran. Panggung, 30(2).

Murwonugroho, W., \& Tyasrinestu, F.
(2019). Visual playability in jogja video mapping. International Journal of Scientific and Technology Research, 8(10), 3395-3400.

Nasir, M. A. (2019). Revisiting the Javanese Muslim Slametan: Islam, local tradition, honor and symbolic communication. Al-Jami'ah, 57(2), 329-358. https://doi. org/10.14421/ajis.2019.572.329-358

Ormrod, J. E. (2016). Human learning (7th ed.). Pearson Education.

Perwitasari, N. H. (2020). Apakah sering bersin merupakan gejala terinfeksi gejala virus corona. Diakses 7 Juli 2020. https://tirto. id/apakah-sering-bersin-merupakangejala-terinfeksi-virus-corona-eHNc

Piaget, J. (1965). The origins of intelligence in children. International Universities Press, Inc. https://doi.org/10.1037/ h0051916

Piaget, J. (2003). The psychology of intelligence. Routledge Classic.

Roy, D., Tripathy, S., Kar, S. K., Sharma, N., Verma, S. K., \& Kaushal, V. (2020). Study of knowledge, attitude, anxiety \& perceived mental healthcare need in Indian population during COVID-19 pandemic. Asian Journal of Psychiatry, 51, 102083. https://doi.org/10.1016/j. ajp.2020.102083

Rozaki, A. (2020). Lockdown kampung: Siasat budaya mengatasi wabah Covid-19. Diakses 3 Juli 2020. https://uin-suka. ac.id/id/kolom/detail/47/blog-post. html

Rubin, M., Neria, Y., \& Neria, Y. (2016). Fear, trauma, and posttraumatic stress disorder: clinical, neurobiological, and cultural perspectives. Interdisciplinary Handbook of Trauma and Culture, 303313. https://doi.org/10.1007/978-3-31929404-9

Scarnera, P. (2016). The myth as a tool for human behavior setting. International Journal of Social Science Studies, 4(7), 1-25. https://doi.org/10.11114/ijsss. v4i7.1612

Susanto, M. R., Retnaningsih, R., Setiawati, S. W., Barriyah, I. Q., \& Putri, W. H. (2019). Social media transformation in the public education: A critical review 
of social change. International Journal of Scientific and Technology Research, 8(7), 462-464.

Tanjung, S. (2017). Deathless after death: Humanize the tradition and celebrate of death in Java. SHS Web of Conferences, 33. https://doi.org/10.1051/ shsconf/20173300067

Wessing, R. (2007). Dislodged tales: Javanese goddesses and spirits on the silver screen. Bijdragen Tot de Taal-, Land- En Volkenkunde, 163(4), 529-555. https:// doi.org/10.1163/22134379-90003694

Womack, K., \& Davis, T. (2006). Mythology, remythology, and demythology: The beatles on film. In Reading the Beatles: Cultural Studies, Literary Criticism, and the Fab Four (pp. 97-109). State Universty of New York Press.

Woodward, M. R. (1985). Healing and morality: A Javanese example. Social Science and Medicine, 21(9), 1007-1021. https://doi. org/10.1016/0277-9536(85)90422-8

Yahya, A. N. (2020). Survei RRI-Indo Barometer: Tingginya kekhawatiran warga atas wabah Covid-19. Diakses 3 Juli 2020. https://nasional.kompas. $\mathrm{com} / \mathrm{read} / 2020 / 03 / 20 / 13185191 /$ survei-rri-indo-barometer-tingginyakekhawatiran-warga-atas-wabahcovid-19?page=all

Zoellner, L. A., Ojalehto, H. J., Rosencrans, P., Walker, R. W., Garcia, N. M., Sheikh, I. S., \& Bedard-Gilligan, M. A. (2020). Anxiety and fear in PTSD. In Emotion in Posttraumatic Stress Disorder. Elsevier Inc. https://doi.org/10.1016/b978-0-12816022-0.00002-8 